\title{
Using Soil and Water Conservation Contests for Extension: Experiences from the Bolivian Mountain Valleys
}

\author{
Aad Kessler · Jan de Graaff
}

Received: 9 December 2005/ Accepted: 16 July 2006/Published online: 11 September 2007

(C) Springer Science+Business Media, LLC 2007

\begin{abstract}
Soil and water conservation (SWC) contests among farmer groups were organized in five rural villages in the Bolivian mountain valleys. The contests were aimed at quickly achieving widespread sustainable results. This article analyzes the effectiveness of these contests as an extension tool. Mixed results were obtained. In three villages, participation rates in the SWC activities introduced in the contests were still high even 2 years after project withdrawal. These were all villages where a solid foundation for sustainable development had been laid before the contests were held. Two years later, most families were still involved in maintenance of the SWC practices introduced in the contests, and many farmers had started to experiment with different soil management practices. However, replications of these SWC practices were not widespread, Conservation Leaders did not continue with their training activities, and the quality of maintenance of the practices was often not satisfactory. In order to become a more effective extension tool and achieve widespread impact, SWC contests must receive continued support by a catalyst agency. Moreover, other SWC contests should also be organized in which practices are not predefined. Given that SWC contests are a low-budget extension tool, local municipalities could become more actively involved.
\end{abstract}

Keywords Soil and water conservation .

Farmer-based extension - Sustainable rural development . Farmer contests · Farmer-to-farmer training .

Bolivian mountain valleys

A. Kessler $(\bowtie) \cdot$ J. de Graaff

Erosion and Soil \& Water Conservation Group,

Wageningen University, Nieuwe Kanaal 11, 6709 PA,

Wageningen, The Netherlands

e-mail: Aad.Kessler@wur.nl

\section{Introduction}

Agricultural development programs and extension services, both in developed and developing countries, struggle with frustratingly low adoption rates of soil and water conservation (SWC) practices. In response, Savenije and Huijsman (1991) called for a "making haste slowly" approach that focuses more emphasis on developing and implementing solutions together with rural people. Numerous experiences, principally from Non-Governmental Organizations (NGOs), have proven that these more participatory (slow) approaches often work and that sustainable livelihoods can be established. Successes to date, however, consist of scattered small-scale projects; widescale impact (haste) has yet to be achieved. The major dilemma remains combining widespread and short term impact (Farrington 1998). In SWC extension in particular, participatory approaches are too limited in scope, while existing governmental extension services are often not participatory enough and not sustainable. Hence, strategies and accompanying methodologies and tools are needed that achieve sustainable results in a short time and on a widespread scale.

Despite urgent calls to modify attitudes and develop strategies for the extension of SWC (Sombatpanit and others 1996), the agricultural extension service in Bolivia has completely disappeared, and a governmental strategy for tackling soil erosion does not exist. NGOs have partially filled this gap, and several small-scale successes were obtained with the participatory introduction of SWC practices. However, these successes have not been reproduced at a large enough scale to have an impact at national (or even departmental) level. Government officials are often not even aware of these experiences, and NGOs themselves generally do not have the capacity for wide- 
Fig. 1 Location of the study area in the inter-Andean valleys of Bolivia

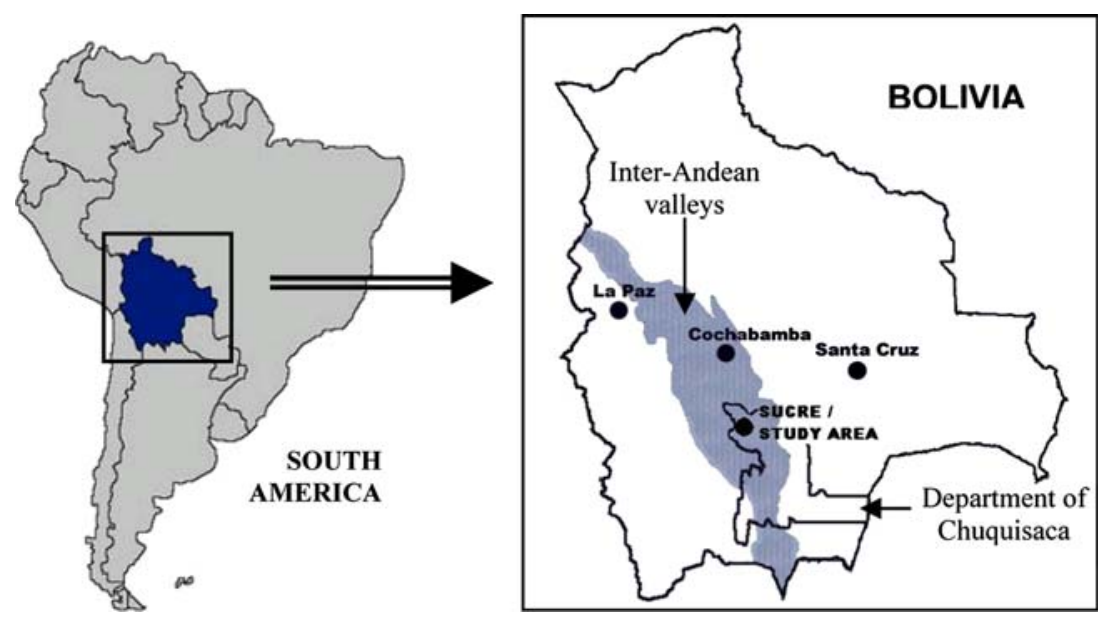

scale dissemination of technology options (Farrington 1998). As a consequence, land degradation during the past decades has increased (Kessler and Stroosnijder 2006), and rural poverty remains a serious threat to sustainable development in Bolivia.

In response, a project executed by the Japan Green Resources Corporation (JGRC) developed and validated a strategy to motivate poor Bolivian mountain farmers to engage in adequate natural resources management, the logical strategy for SWC (Kessler 2007a). Unlike other small-scale participatory experiences, the logical strategy not only aims at slowness but also at making haste (i.e., in finding participatory methodologies and tools that achieve sustainable widespread success in SWC). Scaling-up and integrating SWC in a future extension system at a national level is the ultimate objective. One of the logical strategy's most innovative tools is conducting SWC contests among organized groups of farmers. The objective of this article is to analyze the effectiveness of these SWC contests as an extension tool. This is principally done by monitoring and evaluating farmers' participation in maintaining and replicating SWC practices after execution of the contests. The results will be used to discuss possibilities of using SWC contests in an extension strategy at a national level.

\section{Study Area}

The study was conducted in the five research villages of the JGRC project. They are situated in the north-Chuquisaca region of the inter-Andean valleys of Bolivia (Fig. 1), which is a semi-arid region located at an altitude of 2500 to $3100 \mathrm{~m}$ above sea level. The majority of the families in this region still manage a mixed farming system, with mainly subsistence agriculture and a flock of goats and sheep. Potatoes are still the main crop and are the only crop that receives small amounts of manure. Other important crops are maize, wheat, and barley. Animal traction is mostly used for land preparation. Chuquisaca is one of the least developed areas in Bolivia, with the second lowest Human Development Index (HDI) in Bolivia, equaling only 0.49 (United Nations Development Programme 1997). Similarly, a study by the JGRC project revealed that the Human Poverty Index (HPI) for the research villages is among the highest in the world (on average 45\%), with lack of access to drinking water and health facilities being the principal constraints. Hence, the region is very poor and faces enormous socioeconomic and physical constraints.

In three of the research villages, the "experimental villages" (Tomoroco, Kaynakas, and Sirichaca), the logical strategy was developed and tried out over a period of 4 years. The other two villages were "validation villages" (Talahuanca and Patallajta); in these villages the strategy was validated for 2 years. The villages were carefully selected, in order to obtain a representative sample of villages for the north-Chuquisaca region. Therefore, geographical, climatic, cultural, and socioeconomic characteristics are different among the villages. Rainfall varies from $350 \mathrm{~mm} /$ year (in Tomoroco) to $750 \mathrm{~mm} /$ year (in Kaynakas). Sirichaca has more flat lands for potato production, whereas the other villages have steeper and more erosion-prone slopes.

SWC is a barely developed activity in this region. Since the colonial era, when farmers started using a combination of Spanish and traditional agricultural practices to maintain adequate production levels, practices have not changed much. As a consequence, once cultivable land began to be used more intensively, traditional conservation practices were no longer able to control erosion and maintain soil fertility. Most of the SWC practices currently found in the research villages are still based on traditional knowledge, but given their ineffectiveness in conserving soil and water, farmers have become increasingly sceptical about prospects for sustainable agriculture in their villages. Therefore, migration rates are high in most of the villages. Attempts of development agencies to promote improved 
SWC practices have not been successful, mainly because of failing intervention strategies and the lack of adequate extension tools.

\section{Research Methodology}

The SWC contests were conducted in the "experimental villages" in 2001, and in the "validation villages" in 2003. In each "experimental village" only one SWC contest, which focused on all physical SWC practices, was conducted; in the "validation villages" two SWC contests were conducted, focusing on two SWC practices each. During the SWC contests, the number of labor days invested per family was monitored for each SWC practice. Moreover, the rate of participation in the contests (i.e., percentage of families actively involved in SWC activities) was evaluated in each village.

The most important data for this study were obtained in the ex-post evaluation in 2005, 2 years after the JGRC project's withdrawal from the villages. The ex-post evaluation was conducted in all villages, except Sirichaca. In this village an evaluation was not considered necessary, due to the disappointing results and low participation rates during the contests. In the other villages, a random sample of 30 families was taken for the ex-post evaluation. Although the diversity of farmers within each village is high, and farmers who are progress-driven and economically better-off tend to invest more in SWC practices than others (Kessler 2006), this was not considered a variable. Hence, large families, as well as, for example, widows were included in the sample. Similarly, farmers from the higher economic stratum (with more land) as well as very poor small farmers were considered.

In the ex-post evaluation, the percentage of families actively involved in both maintenance and replications of SWC practices was assessed by means of a field survey. If at least one type of SWC practice was properly maintained, the family was considered to be actively involved in maintenance. If at least one SWC practice was replicated on other fields after the project's withdrawal, the family was considered to be actively involved in replications. Similarly, the active usage of other (nonphysical) SWC practices was evaluated during the ex-post evaluation.

Finally, in order to obtain data concerning the popularity of the executed SWC practices, quality of maintenance of these practices was evaluated within the same sample of families. For each family an average score was given for the quality of maintenance of each type of SWC practice, ranging from very bad (or abandoned) to very good. Based on these scores, and in order to be able to compare the villages, average scores for each village were calculated.

\section{The Need for More Effective Extension Tools}

Although Bolivia has tried out different extension service models (Bojanic 2001), these were always technologycentered and top-down, with weak research-extension linkages. Most widely used was the Training \& Visit extension system, in which knowledge trickled down from the research institutes to the extension worker and finally to the farmers. Farmer participation in this model was mainly functional. In 1991 a World Bank project strengthened the country's research capacity, but extension remained extremely weak, resulting in poor adoption rates of improved practices (Bojanic 2001). In contrast to other developing countries, where low adoption rates forced extension agencies to apply more people-centered extension approaches, the governmental extension service in Bolivia simply disappeared. The research and extension component remained an independent foundation only for the study of potatoes. Currently, a demand-driven research and extension system (SIBTA, the Bolivian Agricultural Technology System) is in place that promotes innovative technologies in support of productive chains. Given the system's focus on promoting regional cash-crops, (poor) subsistence farmers are largely excluded.

In Bolivia, as in many other Latin America countries, NGOs fulfilled the more intensive extension tasks. In contrast to the functional type of participation of public sector organizations, most NGOs aim at an empowering type of participation (Farrington 1998). Several NGO-initiated experiments with Farmer Participatory Research (FPR), were based on the farmer-first approach (Chambers and others 1989). Their pioneering work with a large set of participatory techniques and innovative extension approaches has led to the realization that community participation and integrated (multi-sector) approaches are essential elements for success. In Latin America, farmer-to-farmer extension has had a notable impact and has led to adequate natural resources management in Mexico (Ramos 1998), Honduras (Sherwood and Larrea 2001), and Nicaragua (Braun and Hocdé 2000), among other countries. Given that NGOs can spend considerable resources in a few villages, and often invest in time-demanding and costly faceto-face participation, they have achieved higher participation rates than governmental extension services. However, the principal constraint of these extension approaches is their limited scope: they are difficult to replicate on a wide scale in the absence of local support organizations (Farrington and others 2002). With the prime objective of agricultural extension being to reach all farmers, this is a crucial constraint.

The JGRC project's logical strategy for SWC is not the first attempt to develop effective strategies that combine farmer participation at the grassroots level with extension 
and scaling-up. Killough (2005), for example, proposes "participatory extension through [the] accompaniment model." This extension approach is a middle road between the traditional extensionist-centered approaches and the more recent farmer-led approaches. In this model, professional extension workers help farmer-promoters conduct on-farm experiments and provide farmer-to-farmer training. Local empowerment (through the development of farmer leaders) and strengthening local institutions are primary goals of this holistic approach. It is therefore important that such extension approaches promote integrated human development. Evidence from Honduras shows that farmers would have likely abandoned SWC practices long ago, if the extension approach had not addressed essential aspects of the interaction between human development and agriculture (Sherwood and Larrea 2001). Farmers conceptualized this interaction and holistic approach as "the human farm."

Implementing such an integrated and farmer-based extension approach is urgently needed in Bolivia; only then can a wide-scale impact be achieved. Although municipalities have considerable budgets for rural development, they do not have the human capacity to provide this service, and they regard extension as a state responsibility. Hence, there is a need for (1) profound changes at institutional level to give priority to extension, and (2) effective extension tools that can be used in a farmer-based extension approach. SWC contests are an example of such a tool.

\section{Using SWC Contests Within a Farmer-Based Extension Approach}

Organizations in several countries have experimented with farmer contests or competitions. The State Farm Bureaus in the United States regularly hold such contests, in particular for young farmers. Management, growth and progress in farming operations are major factors in judging the contests. The outstanding farmers receive financial awards, which are usually made available by sponsors. Farmer competitions in New Zealand and Australia are more focused on developing technical skills and knowledge, with conservation and land management practices being one of the several competition modules. In developing countries all kinds of farmer contests are held, but rarely focused on SWC. Chuma and Murwira (1999) report of farmer competitions in Zimbabwe organized to stimulate the process of experimentation and revival of farmer knowledge regarding best farming practices.

The best results with respect to SWC have been achieved in two rural development projects in Bolivia and Peru, where SWC contests among farmers were used to speed up execution of SWC practices. Both projects make use of the "learning from the best" principle (i.e., learning from the best families and villages) (Van Immerzeel and De Zutter 2005). Knowledge management (i.e., combining knowledge and capacities from different farmers to find sustainable and fast solutions) is essential in this approach. The contests are used as a catalyst tool to disseminate this knowledge and motivate farmers to learn from the best, to experiment and innovate, and to win prizes by improving on what they have learned (Van Immerzeel and De Zutter 2005).

In Peru, the rural development project, MARENASS (Management of Natural Resources in the Southern Highlands), uses farmer contests to promote new technological practices for improving natural resources management, agricultural production and living conditions. An important characteristic of the project is the transfer of decisionmaking and responsibility for planning and financial resources to the villages. Each participating village receives financial support to hire direct technical assistance (Posthumus 2005). These external service providers can be farmers with much experience ("the best farmers"), consultants or technical staff members. When a contest is organized, the villages themselves select and contract these privatized services to provide training to a number of selected farmers. By means of farmer-to-farmer training, the trained farmers in turn teach the other villagers the new techniques they have learned. Contests are held both at village level, with farmers competing against each other, and on district level between villages (Posthumus 2005). Jury members are selected by the participants; the families, or villages that best apply the recommendations provided by technical staff earn a cash prize. The innovations of MARENASS have been successful, and the project is still in progress (International Fund for Agricultural Development 2005); in 360 villages about $60 \%$ of all households have been reached (De Zutter 2004). Nevertheless, since internal problems in some villages limit their participation in the project, the impact of activities on watershed level is quite low (Posthumus 2005).

In Bolivia, the SID (Strategies for International Development) project, Pachamama Urupa, approaches the dual problems of soil erosion and rural poverty with the understanding that neither can be resolved without simultaneously addressing both. Competitions among villages are organized to encourage participation in natural resources management, and to recognize the most successful farmers (Strategies for International Development 2005). SID hires farmers who are skilled in one or more of the land conservation and reclamation practices as parttime staff. These para-professional extension agents train selected farmers in about five villages, who in turn train all the other participants of the contest in their respective villages (Borda 2002). The competitions are flexible 
enough to permit farmers to find their own solutions to their problems (i.e., to experiment and innovate). All farmers participate in the judging, which stimulates the sharing of knowledge and the adoption and improvement of the practices. The winning villages and families receive farm tools, seeds, and animals as prizes. Participation rates in the competitions are about $80 \%$ to $90 \%$. The project has recently won the World Bank's "Development Marketplace Competition" for innovative ideas in international development.

The MARENASS and SID projects are quite similar; they aim at wide-scale adequate natural resources management through a farmer-based extension approach that builds on local knowledge and capacities. Massive participation in farmer contests and farmer-to-farmer training are crucial aspects of this approach. Moreover, progressive learning and improvement is stimulated through constant interchanges, the participatory judging process and the closing ceremonies. Two important differences between the projects are that:

- in Bolivia the practices being judged in a contest are specifically defined, while in Peru the contests have a more general character (e.g., soil conservation) and practices are not specified;

- in Bolivia money is not involved (and prizes are in the form of goods), while in Peru farmers are responsible for contracting the trainers and cash prizes can be won.

Based on these experiences, SWC contests are undeniably a very promising tool for farmer-based extension strategies, and for achieving fast and widespread sustainable impact in natural resources management. In the following section we will focus on the SWC contests of the JGRC project.

\section{SWC Contests in the JGRC Project}

In the logical strategy of the JGRC project, SWC practices are executed within a framework of integrated rural development. They are always accompanied by - and often integrated in - other activities that aim at improving local livelihoods. An important feature of this strategy is the laying of a solid foundation for sustainable development before starting a SWC contest, with activities focusing, for example, on better village organization, responsible participation and effective collaboration (Kessler 2007b). The project's strategy stresses the human dimension of sustainable development: genuine participation of stakeholders is essential (Kessler 2007a). The objective of the SWC contests is to train farmers in basic SWC practices. Moreover, the contests encourage farmers to experiment and to decide which practices best fit their specific conditions.
Reflection and dialog - two key features of Participatory Research \& Extension (Percy 2005) - are constantly used. Participatory research with a selected group of farmers, as well as farmer-to-farmer training and knowledge transfer, are crucial before, during and after the SWC contests. Lessons learned through the farmer-to-farmer movement that began in the Guatemalan highlands (Bunch 1982) are, therefore, taken into account (e.g., to use small-scale experimentation) to start slowly and small, to achieve early recognizable success and to limit the introduction of technology. The essential multiplier effect is provided by the SWC contests and farmer-to-farmer training.

In the next section we explain the SWC contests in more detail. In all the activities the project's extension worker plays a crucial role. At the end of the section we also present the differences between the approach of the aforementioned two projects and the JGRC project.

\section{Activities Preceding the SWC Contests}

Preceding the SWC contests (i.e., during the laying of a solid foundation for sustainable development in a village), SWC activities start with a group of about 10 Conservation Leaders (CLs). CLs are chosen by the assembly, taking into account personal characteristics such as responsibility, honesty and willingness to innovate. They receive intensive training from the project's extension worker, aiming at the generation of a progress-driven attitude and at conducting experiments on their fields. Experimentation focuses both on physical SWC practices (stone lines, diversion ditches, bench terraces, etc.) and agronomical soil management practices (more efficient manure use, composting, green manure, etc.). CLs are also stimulated to establish some test-sites for comparing with and without cases, with the objective of obtaining more visible results and making onsite comparisons. This might convince visiting farmers that the positive effects are indeed a result of the practices, and not of different physical conditions between their farm and the CLs' farms. Apart from experimentation and providing demonstrations on their own farms, CLs also have many less tangible tasks such as mobilizing the villagers to become involved in development activities. They are thus both promoters and technicians. Finally, training of CLs in techniques for knowledge transfer is given before and during the farm visits.

Once a solid foundation is laid in the village and CLs are sufficiently trained, the group decides when the first SWC contest will be held and which practices will be executed. In the dry season, practices like stone lines and gully control measures are considered and in the wet season practices that require digging such as diversion ditches and bench terraces. The village is informed in the assembly and 
by distributing information leaflets. During a period of at least a few weeks, families have the opportunity to decide whether to participate in the contest. CLs have an active role in motivating their neighbors, and in starting to organize groups based on vicinity. Eventually, each CL should lead a group of five to eight families. During these weeks of group formation, possible conflicts must be resolved, especially between neighbors. Given that effective group collaboration is crucial for a successful SWC contest, group formation should be given the required time.

\section{Execution and Evaluation of the SWC Contests}

A contest generally deals with two SWC practices. In a later stage a certain contest can be repeated and/or more integrated contests can be considered, combining different practices. The first contest is the most important one, because it serves as a selection tool for distinguishing the interested families (those with a progress-driven attitude) from the others. In this first contest a subsidy is given - as an incentive to all participants - for the purchase of a set of tools that are essential to conduct SWC practices. Each family pays $20 \%$ of the original cost. Families that start participating in a later stage have no access to the subsidized tools, and should themselves catch up with the already executed practices.

Each SWC contest takes about one or two months. Twice a year a contest can be held; one in the dry season and the other one in the wet season. The criteria for evaluating the contests are clearly indicated before starting: (1) executed quantity, (2) quality of the work, (3) knowledge, and (4) group collaboration. Major emphasis is given to training and learning during the contests. An essential technique for conducting most of the SWC practices is the adequate handling of the A-frame, which is used for establishing the contour lines in a field. This is generally taught during the first contest.

Once the contest starts, each group - under the guidance of their CL - decides how the work will be done. Reciprocal group work (or "ayni" in Quechua) is mostly used. In this system, farmers work on each others' farms on a rotation basis. It is especially useful for labor-intensive work, and hastens the pace of execution. The host family provides food; money is never used. Reciprocity in the Andes region is based on mutual trust. Torrico and others (1994) argue that it still contains many religious aspects, and that, therefore, quality of the work is never discussed. Similar to the "alayon", a traditional form of village cooperation in the Philippines (Moneva and others 2000), the ayni serves as a venue for group learning, problem solving and the promotion of equitability among farmers. SWC practices are mainly conducted on fields situated near the farmer's homestead; later they can be replicated on other fields. The project's extension worker regularly monitors group work, and assists the CLs in their training. In the beginning, CLs often encounter problems and feel uncertain; regular meetings help to solve this.

Once a contest has finished, each CL measures the quantity of practices executed by his or her group. The verification of this quantity, as well as the evaluation of quality and knowledge, is done by means of cross-visits with other CLs. Quality criteria are harmonized between CLs before starting the evaluation. Knowledge is evaluated by asking some practical questions. For these three criteria (quantity, quality and knowledge) scores of 1 (bad) to 3 (good) can be obtained. This is written down on evaluation sheets. Based on observations, the extension worker evaluates the fourth criterion: group collaboration and cohesion. All criteria are given the same weight-factor in the final calculation.

During the final closing ceremony the groups receive a reward for their efforts. Recognition of efforts is important because it engenders a sense of pride and it increases selfconfidence (Cinnéide and Conghaile 1990). The most recommendable rewards are seeds for green manure and vegetables, which contribute to more sustainable agriculture. Additionally, the winning groups also receive, for instance, potato, maize, or barley seeds, all in small quantities. These prizes are useful products and their value is small enough to avoid participating in the SWC contests for the wrong reason. In this respect, money or food must never be used as prizes.

\section{Activities Succeeding the SWC Contests}

Maintenance of the newly constructed practices is the first priority, and complementary vegetative and soil management practices are essential in order to achieve impact on soil productivity. Vegetative conservation practices (grasses, bushes, or trees) also strengthen most SWC practices and make them more sustainable. They require, however, controlled grazing and strict rules at village level that are respected by all villagers. Hence, only when such regulations are collectively agreed upon will vegetative practices be viable and will SWC practices work.

Given the importance of vegetation, establishing tree nurseries in each village - preferably at family level - is part of the holistic approach of the logical strategy. By means of an Integrated Project (Kessler 2007a), a group of farmers interested in agroforestry is trained to become trainers in this topic. Through farmer-to-farmer training, technical knowledge regarding agroforestry practices can be spread to a large number of farmers. Similarly, other groups of farmers specialize in, for example, manure 
Table 1 Average number of labour days invested per family for each SWC practice, during the SWC contests

Source: M\&E data in 2001 (experimental villages) and 2003 (validation villages)

\begin{tabular}{lllllll}
\hline SWC practices & \multicolumn{2}{l}{ Experimental villages } & & \multicolumn{2}{l}{ Validation villages } \\
\cline { 2 - 3 } & Tomoroco & Kaynakas & Sirichaca & & Talahuanca & Patallajta \\
\hline Stone lines & 8.1 & 5.6 & 4.5 & & 5.2 & 5.4 \\
Diversion ditches & 0.8 & 0.8 & 1.2 & & 2.8 & 2.8 \\
Gully control & 0.3 & 0.6 & 1.8 & & 0.5 & 2.5 \\
Bench terraces & 2.1 & 2.7 & - & & - & - \\
Earth bunds & - & 0.1 & 1.6 & & 0.2 & 1.1 \\
Infiltration ditches & 0.2 & 0.3 & - & & - & - \\
Individual terraces & - & 0.5 & 1.4 & & - & - \\
Total & 11.5 & 10.7 & 10.5 & & 8.9 & 11.8 \\
\hline
\end{tabular}

management (improved stables, manure storage and collection methods), composting or green manure practices.

The spreading and replication of SWC practices to all the other fields that need to be conserved is the responsibility of each family. Although, ideally, groups that participated in the SWC contest will continue to work in ayni, most families will have to do it on their own. The role of the CLs is to provide support whenever it is requested.

\section{Differences with the MARENASS and SID Projects}

Although similar in many aspects, especially in considering SWC as being part of an integrated approach to sustainable rural development, the JGRC project conducted its SWC contests in a slightly different way than the MARENASS and SID projects. This concerned four crucial aspects:

1. The emphasis on training in specific SWC practices during each contest instead of leaving more space for experimentation. The reason: the SWC contests are foremost an extension tool, i.e., they aim at providing farmers with basic practical knowledge of some simple SWC alternatives. After the contests farmers experiment with innovations and will adapt and improve the practices.

2. The emphasis on laying a solid foundation for sustainable development before starting the SWC contests. The reason: only farmers with a progressdriven attitude will continue to experiment and innovate after the project's withdrawal.

3. The use of contests between groups instead of families or villages. The reason: to stimulate group formation and collaboration within a village, i.e., to maintain or re-establish the traditional work in ayni, and to contribute to better internal relations and knowledge exchange.

4. The subsidizing of tools to stimulate participation in the contests, but no (or insignificant) prizes for winning groups. The reason: not having the tools is often a major limitation for participating, but once farmers participate, they must become convinced by the result of their work and not by the prizes they can win.

\section{Results and Discussion}

Table 1 shows that similar numbers of family labor days were invested during the SWC contests in all villages. Groups generally worked two aynis (or two complete labor days) on each group member's fields. Stone lines were the most popular practice executed during the contests, with labor accounting for $40 \%$ to $70 \%$ of total labor days invested. In Tomoroco and Kaynakas - with more steeply sloping land - considerable investments were made in bench terraces, while in Sirichaca and Patallajta gully control works (especially the smaller ones) and earth bunds (due to the absence of stones) were given more attention.

Table 2 shows that the percentage of families participating in the construction of practices during the SWC contests was lowest in Sirichaca (48\%) and Patallajta $(66 \%)$; these are both villages in which a solid foundation for sustainable development was never laid. In Tomoroco the participation rate was highest with $86 \%$. These data show that in the villages where activities concerning organization, collaboration and environmental awareness raising had already been successfully executed, the SWC contests were able to mobilize more people.

However, initial motivation is easy; continued motivation is what really matters (Savenije and Huijsman 1991). The effectiveness of the SWC contests can only be properly measured by evaluating the continued use of SWC practices after the project's withdrawal. Table 2 shows the results of the ex-post evaluation, in which the percentage of families that have maintained and replicated SWC practices was assessed.

Concerning maintenance, in Tomoroco this percentage is highest and has even increased; presently, $91 \%$ of all families perform adequate maintenance of one or more 
Table 2 Percentage of families actively involved in SWC activities

\begin{tabular}{|c|c|c|c|c|c|}
\hline \multirow[t]{2}{*}{ SWC activity } & \multicolumn{3}{|c|}{ Experimental villages } & \multicolumn{2}{|c|}{ Validation villages } \\
\hline & Tomoroco & Kaynakas & Sirichaca & Talahuanca & Patallajta \\
\hline Construction of SWC practices during the SWC contests & 86 & 75 & 48 & 84 & 66 \\
\hline Maintenance of SWC practices two years after project withdrawal & 91 & 69 & - & 84 & 53 \\
\hline Replications of SWC practices two years after project withdrawal & 78 & 25 & & 20 & 30 \\
\hline
\end{tabular}

Source: M\&E data in 2001 and 2003 (during the contests) and ex-post evaluation data in 2005

Table 3 Quality of maintenance of SWC practices two years after project withdrawal

\begin{tabular}{llllll}
\hline SWC practices & \multicolumn{2}{l}{ Experimental villages } & & \multicolumn{2}{l}{ Validation villages } \\
\cline { 2 - 3 } \cline { 5 - 6 } \cline { 5 - 6 } & Tomoroco & Kaynakas & & Talahuanca & Patallajta \\
\hline Stone lines & + & $+/-$ & ++ & $+/-$ \\
Diversion ditches & $+/-$ & $+/-$ & & + & - \\
Gully control & $+/-$ & - & & $+/-$ & $+/-$ \\
Bench terraces & + & + & & n.a. & n.a. \\
Earth bunds & n.a. & n.a. & - & - \\
\hline
\end{tabular}

++ very good; + good; +/- moderate; - bad; - very bad (abandoned); n.a. not applicable (not executed)

Source: Ex-post evaluation data in 2005

SWC practices. Quality of maintenance was moderate to good in Tomoroco (Table 3); stone lines and bench terraces were especially well maintained. In Kaynakas 6\% fewer families are currently involved in SWC activities; some families have not maintained their practices or have even removed stone lines and gully control measures. In some cases stones from stone lines were used for fruit tree terraces; such farmers experimented with and adapted practices. Farmers often refine their practices under environmental pressure (Veihe 2000). They may, for example, consider stones more effective for terrace building than for stone bunds. This is supported by Table 3: in Kaynakas the quality of maintenance is better for bench terraces than for stone lines. Bench terraces are popular and productive for vegetables.

Abandonment of SWC practices is highest in Patallajta, where two consecutive severe drought years and lack of impact of SWC practices caused general disillusion among the villagers. Migration increased and fields were left unattended. Table 3 shows that quality of maintenance is bad to moderate in this village; earth bunds, which were heavily damaged during a high-intensity rain storm, were all abandoned. In neighboring Talahuanca, however, despite severe drought and similar damage to earth bunds, all participating families in the SWC contests are still actively involved in maintenance, except for earth bunds. The presence in Talahuanca of a solid foundation for sustainable development before starting the SWC contests explains the differences between both 'validation' villages. Maintenance of gully control measures was generally given little attention in all of the villages, although most people are of the opinion that these practices work very well.

Concerning replications, a field survey in 2003 revealed that in Tomoroco and Kaynakas wide-scale replications were conducted during the two years in which the JGRC project was in effect. All participating families in the SWC contests constructed new SWC practices. This was mainly attributed to the inclusion of SWC activities in other activities of the JGRC project (namely Integrated Projects, see Kessler 2007a). Stone lines and diversion ditches were mostly replicated and covered large areas of the agricultural land in both villages. The average investment in these villages in maintenance and replications of SWC practices was estimated to be 20 labor days per family during these two years (2001 to 2003).

However, more important from a sustainability viewpoint is what happened after the project's withdrawal (starting in 2003). Table 2 shows that in Tomoroco $78 \%$ of all families constructed replications of SWC practices in the subsequent two years; in the other villages this was much lower (about 25\%). Stone lines, especially, were replicated, given their relatively low labor requirements. The differences between the villages are explained by the fact that Tomoroco has more potential land for constructing stone lines, while in Talahuanca and Kaynakas the most important fields had already been protected. Moreover, on the steeper slopes of Kaynakas, stone lines sometimes disturb land preparation. In this village bench terraces were found more useful, but their replication requires higher investments. Replications of stone lines were found in only one village outside the project area, near Tomoroco..

Hence, the SWC contests have achieved mixed results in the five villages. They were effective in three villages: Tomoroco, Kaynakas and Talahuanca. The most positive outcome is that in these villages (on average) more than $80 \%$ of the families are currently involved in one way or another in SWC activities, and this was achieved without using incentive schemes or cash prizes. Most villagers also consider the executed SWC practices useful, and more than half of the farmers plan to replicate more measures in the 
Table 4 Percentage of families using other SWC practices two years after project withdrawal

\begin{tabular}{|c|c|c|c|c|c|}
\hline \multirow[t]{2}{*}{ SWC practices } & \multicolumn{2}{|c|}{ Experimental villages } & \multicolumn{2}{|c|}{ Validation villages } & \multirow[t]{2}{*}{ Observations } \\
\hline & Tomoroco & Kaynakas & Talahuanca & Patallajta & \\
\hline Manure use & 36 & 16 & 5 & 0 & Improved traditional practice \\
\hline Green manure & 20 & 0 & 10 & 0 & New practice \\
\hline Crop rotations & 60 & 28 & 30 & 15 & Improved traditional practice \\
\hline Strip cropping & 24 & 12 & 15 & 0 & New practice \\
\hline Agroforestry & 28 & 64 & 25 & 45 & New practice \\
\hline Mixed cropping & 68 & 48 & 70 & 65 & Improved traditional practice \\
\hline Composting & 40 & 20 & - & 10 & New practice \\
\hline
\end{tabular}

Source: Ex-post evaluation data in 2005

near future. The three villages have in common that they all have solid foundations for sustainable development, which were laid before the SWC contests were conducted (in the first Phase of the logical strategy). This has triggered a renewed interest in alternatives to improve living conditions, including better soil management. The most negative outcomes are that in two of these villages (Kaynakas and Talahuanca) replication rates are currently very low, and in all villages CLs are no longer active as trainers. It seems that the dynamics of the process came to a halt after the project's withdrawal. Some farmers cautiously experiment and replicate SWC practices, but most of them only maintain existing practices and wait for tangible results before investing in new ones. Similarly, the CLs find themselves in a vacuum; they are rarely asked for advice, and there is no common objective to keep the CLs' groups active. The catalyst of the process, the project, is no longer there. The CLs were expected to fulfill this motivating role after the project's withdrawal, but this has not happened.

On the other hand, in Tomoroco and Kaynakas the landscape has visibly changed due to the installed SWC practices, and internal regulations concerning controlled grazing are being complied with (Kessler 2007a). According to the respondents in the ex-post evaluation, SWC contests work; $80 \%$ of respondents are positive about the actual impact of the contests. Most importantly, for many farmers the experiences acquired during the contests with alternative techniques and practices have served as a basis for experimentation. Under the marginal conditions of poor farmers, adapting innovations is more important than adopting innovations (Van de Fliert and Braun 2002). The message that alternatives are available to improve productivity has come through; people are interested and have started to experiment with new techniques.

In this respect, it is interesting to observe the usage of other SWC practices that were not included in the contests, but are now practiced by interested farmer groups and CLs. Table 4 shows that several of these practices are currently in use by a considerable number of families, especially improved traditional practices like crop rotations (including leguminous crops) and mixed cropping systems. Hence, knowledge transfer from farmer to farmer does also occur spontaneously. If these SWC practices would have been included in the SWC contests, their adoption rate could have been much higher. Therefore, a first recommendation of this paper is to also conduct SWC contests in which practices are not previously defined. The contests described in this paper filled an important knowledge gap and provided farmers with basic information. However, the failure of earth bunds and the removal of other practices by several families prove that only executing contests with some predefined practices is not enough. Stimulating people's creativity and having each individual family decide which management practices best fit their conditions is considered crucial in the MARENASS and SID projects (Van Immerzeel and De Zutter 2005). Local adaptations of existing practices will become available sooner if more space is left for farmers' initiatives during the contests. Hence, the JGRC-type of contests can be maintained as a training tool, but other (more general) SWC contests should be organized as a follow-up activity.

A second recommendation is to strengthen the role of local organizations in providing follow-up support to the SWC contests. The major weakness of the JGRC project was its incapacity to institutionalize the process: SWC activities continued at a high rate when the project fulfilled its catalyst function, but drastically decreased after the project's withdrawal. Of course, municipalities were always involved in the activities, but their genuine participation was not achieved. Longer-lasting institutional support in organizing and facilitating more SWC contests would have strengthened the CLs' role, and would have kept the dynamic process going. To some extent, farmers can respond to land degradation without external support, but they need continued provision of technical assistance and information in order to make progress (Paudel and Thapa 2001). Farmers have often lost the self-confidence and capacity to adapt and innovate (Reijntjes and others 
1998); without external support they will continue to farm in the way they have in the past (Percy 2005). Given that SWC contests are a low-budget extension tool, they can be easily organized by municipalities and local NGOs, for example. However, despite the involvement of local leaders during the SWC contests, the active involvement of many extension workers is needed, especially when larger areas are to be covered in order to achieve a wide-scale impact. This can be a major limitation for local institutions; policies at the macro-level that enable the implementation of a farmer-based extension approach are therefore required. Earlier in this paper we already mentioned that in Bolivia profound changes at institutional level are required that give priority to extension. Only when such changes are made can SWC contests become an effective extension tool "to make haste slowly."

In Bolivia, to date, governments have never committed themselves to extension; strategies were not clearly defined and the extension service constituted a large burden on the state budget (Bojanic 2001). Presently, many participatory approaches and tools are available (Chambers and others 1989) that have proven their effectiveness over the last decades. Based on case studies in Thailand and Laos, Connell (2000) concludes that there are several opportunities for the institutionalization of participatory approaches in mainstream extension, but that they all require significant political commitment. Particularly regarding environmental problems, different interest groups often pull in complementary and opposing directions (Röling and Pretty 1997). The challenge ahead for effective extension is to combine efforts. This has been done in Chile, where the government has contracted private technology companies to cater for the larger commercial farmers, and NGOs for small subsistence-oriented farmers. Rivera and Qamar (2003) for example propose a mixture of funding and service delivery modalities; governments could provide funding and NGOs could deliver the extension services. If the political willingness is present, this could also present an interesting opportunity in Bolivia.

\section{Conclusions}

The challenge we face in SWC is to quickly achieve widespread sustainable results, i.e., "to make haste slowly" (Savenije and Huijsman 1991). Based on the success of SWC contests elsewhere in the Andes (Van Immerzeel and De Zutter 2005), the JGRC project used this innovative tool in five rural Bolivian villages to put "making haste slowly" into practice. Mixed results were achieved with SWC contests between farmer groups. On the one hand, in villages where a solid foundation for sustainable development had already been laid, participation rates in the SWC contests were high.
Most farmers were still involved in SWC activities even two years after project withdrawal, without receiving any incentive. In these villages large areas are currently protected with physical SWC practices and farmers have also started to experiment with other soil management practices. On the other hand, in the same villages the renewed system of collaboration focused on SWC was lost when the project withdrew, and Conservation Leaders did not continue with their training activities. Despite the visible widespread impact of the contests, sustainability is thus not yet assured. Farmers easily become disillusioned and unmotivated in the absence of a catalyst to keep the process of SWC contests and farmer-to-farmer training going. Moreover, tangible results such as higher soil productivity take a long time to appear. Farmers are opportunistic; in poor regions like the Bolivian mountain valleys, especially, they will grasp any opportunity to increase income.

Two recommendations were given in this paper to make SWC contests more effective in an extension strategy. First, in addition to the contests described here, other SWC contests should be organized in which practices are not predefined; this will stimulate peoples' creativity in developing adaptations of existing practices. Second, commitment is required from local institutions to support SWC contests as an extension tool; only then can Conservation Leaders continue their activities, and can a widespread impact be achieved. Given the responsibility of Bolivian municipalities for rural development, they must be the first to become actively involved in extension. However, steering and support with adequate strategies from departmental and state institutions is indispensable; this will motivate municipalities to take natural resources conservation and rural development more seriously. Without such support, any attempt to spread SWC practices via participatory extension methodologies - such as farmer contests - will likely fail; no matter how logical and welldesigned the strategy may be.

Acknowledgments The authors wish to thank the whole team of the former JGRC project in Sucre, especially the excellent Bolivian professionals Edwin Arteaga, Hugo Uzeda and Elizabeth Barroso, as well as the ever-dedicated extension workers Arnulfo Borges, Victor Duran, Fernando Flores and late Constantino Loayza. Thanks also to Dr Hideo Ago for his inspiring ideas, and to two anonymous referees for their constructive comments. The financial support for this research came from the JGRC project.

\section{References}

Bojanic AJ (2001) Extension, poverty and vulnerability in Bolivia and Colombia. Country Studies for the Neuchâtel Initiative. Overseas Development Institute, London

Borda A (2002) Estrategias para recuperar el altiplano. in Memorias del 2do Taller Internacional. Serie "Seminarios y Talleres", Documento 2. JGRC, Sucre. Pages 128-135 
Braun AR, Hocdé H (2000) Farmer Participatory Research in Latin America: Four Cases. In: W.W. Stur et al. (Eds.) Working with Farmers: The Key to Adoption of Forage Technologies. ACIAR Publication PR095. Pages 32-53

Bunch R (1982) Two ears of corn. A guide to people-centred agricultural improvement. World Neighbours, Oklahoma City

Chambers R, Pacey A, Thrupp LA (1989) Farmer First. Farmer innovation and agricultural research. Intermediate Technology Publications, London

Chuma E, Murwira K (1999) Farmers' management of risk: experiences of the indigenous soil and water conservation project in Zimbabwe. In: Risk management for maize farmers in drought-prone areas of South Africa. Proceedings of a workshop held at Kadoma Ranch, Zimbabwe. CIMMYT, Mexcio D.F

Cinnéide MO, Conghaile MO (1990) Promoting local initiative through a community development competition. Journal of Rural Studies 6:325-329

Connel JG (2000) Scaling-up: The roles of participatory technology development and participatory extension approaches. In: W.W. Stur et al. (Eds.) Working with Farmers: The Key to Adoption of Forage Technologies. ACIAR Publication PR095. Pages 69-82

De Zutter P (2004) Diez claves de éxito para el desarrollo rural. Fondo Internacional de Desarrollo Agrícola, Lima

Farrington J (1998) Organizational roles in farmer participatory research and extension: lessons from the last decade. Natural Resources Perspectives 27. ODI-DFID

Farrington J, Christoplos I, Kidd A, Beckman M, Cromwell E (2002) Creating a policy environment for pro-poor agricultural extension: The who? What? and How? Natural Resources Perspectives 80. ODI-DFID

International Fund for Agricultural Development (2005) Marenass is our project. Evaluation Profile 15. IFAD, Rome

Kessler CA, Stroosnijder L (2006) Land degradation by farmers in Bolivian mountain valleys. Land Degradation and Development 17:235-248

Kessler CA (2006) Decisive key-factors influencing farm households' soil and water conservation investments. Applied Geography 26:40-60

Kessler CA (2007a) Motivating farmers for soil and water conservation: A promising strategy from the Bolivian mountain valleys. Land Use Policy 24:118-128

Kessler CA (2007b) Laying a solid foundation for sustainabledevelopment in Bolivian mountain villages. Environment, Development and Sustainability doi: 10.1007/s10668006-9062-3

Killough S (2005) Participatory approaches to agricultural research and extension. In: Gonsalves J et al. (Eds.) Participatory research and development for sustainable agriculture and natural resource management: a sourcebook. Volume 1: Understanding Participatory Research and Development. CIP-UPWARD/IDRC. Ottawa. Pages 23-31

Moneva LA, Cadao JB, Jackson J (2000) Farmer-Based Extension in the Phillipines: The World Neighbours - Mag-uugmad Foundation experience. In: W.W. Stur et al. (Eds.) Working with
Farmers: The Key to Adoption of Forage Technologies. ACIAR Publication PR095. Pages 91-93

Paudel GS, Thapa G (2001) Changing Farmers' Land Management Practices in the Hills of Nepal. Environmental Management 28:789-803

Percy R (2005) The contribution of transformative learning theory to the practice of participatory research and extension: Theoretical reflections. Agriculture and Human Values 22:127-136

Posthumus H (2005) Adoption of terraces in the Peruvian Andes. Tropical Resource Management Papers 72. Wageningen University, Wageningen

Ramos FJ (1998) Grupo Vicente Guerrero de Espanita, Tlaxcala. Dos décadas de promoción de campesino a campesino. Red de gestión de Recursos Naturales and Rockefeller Foundation, Mexico City

Reijntjes C, Minderhoud-Jones M, Laban P (1998) Participatory learning, planning and action towards LEISA. LEISA in perspective - 15 years ILEIA. ILEIA, Leusden

Rivera WM, Qamar WM (2003) A new extension vision for food security. Challenge to change. Sustainable Development Department. FAO, Rome

Röling N, Pretty JN (1997) Extension's role in sustainable agricultural development. In Improving agricultural extension: a reference manual. FAO, Rome

Savenije A, Huijsman H (1991) Making haste slowly: Strengthening Local Environmental Management in Agricultural Development. Royal Tropical Institute, Amsterdam. 239 pp

Sherwood S, Larrea S (2001) Looking back to see ahead: Farmer lessons and recommendations after 15 years of innovation and leadership in Güinope, Honduras. Agriculture and Human Values 18:195-208

Strategies for International Development (2005) Combating soil erosion and rural poverty in Bolivia \& How you can help. SID, http://www.sidworld.org

Sombatpanit S, Zöbisch MA, Sanders DW, Cook MG, Enters T, Hagmann J, Renaud FG, Theerawomg S (1996) Report on the International Workshop on Soil Conservation Extension: Concepts, Strategies, Implementation and Adoption. Soil and Water Conservation Society of Thailand, Bangkok

Torrico D, Lisperguer G, Fernández D, San Martín J (1994) Apuntes sobre Reciprocidad. Serie Técnica 32. AGRUCO, Cochabamba

United Nations Development Programme (1997) Índices de Desarrollo Humano y otros indicadores sociales en 311 municipios de Bolivia. UDAPSO, La Paz

Van de Fliert EM, Braun AR (2002) Conceptualizing integrative, farmer participatory research for sustainable agriculture: From opportunities to impact. Agriculture and Human Values 19:2538

Van Immerzeel WHM, de Zutter P (2005) Eradicating poverty by developing peoples' capacities. Experience and a novel methodology for Latin America. DEXCEL, Cusco - La Paz, 141 pp

Veihe A (2000) Sustainable Farming Practices: Ghanaian Farmers' Perception of Erosion and Their Use of Conservation Measures. Environmental Management 25:393-402 